\title{
INTERCURRICULAR RELATIONSHIP DEVELOPMENT USING ICT TOOLS
}

\section{Dana PALOVÁ - Dáša HUDÁKOVÁ}

\begin{abstract}
The article presents our experience with transformation previous students' knowledge in the field of financial mathematics into practical level using ICT tools.
\end{abstract}

Key words: education, ICT tools, financial mathematics.

\section{ROZVÍJANIE MEDZIPREDMETOVÝCH VZŤAHOV POMOCOU NÁSTROJOV IKT}

Resumé: V rámci príspevku prezentujeme naše skúsenosti s transformáciou teoretických vedomostí študentov z oblasti finančnej matematiky do praktických skúseností s využitím nástrojov IKT.

Klíčová slova: vzdelávanie, nástroje IKT, finančná matematika.

\section{1 Úvod}

Informačné a komunikačné technológie (IKT) sú dnes jedným z najrýchlejšie sa rozvíjajúcich odvetví. Ich vplyv môžeme sledovat' takmer v každej oblasti života l'udskej populácie. Ich rozvoj ovplyvňuje vývoj ekonomík jednotlivých štátov, vzdelávanie, medicínu a pod.

Aplikácia IKT voblasti ekonómie je nepopieratel'ná a je preto nevyhnutnost'ou, aby aj absolventi ekonomicky zameraných vysokých škôl boli pripravení pri riešení úloh v praxi správne využívat' vhodné IKT a ich možnosti. Myslíme si, že najlepším spôsobom ako sa to naučit', je začat' aktívne ich používat' už počas štúdia.

Často sa diskutuje o probléme využitia výpočtovej techniky ako podporného prostriedku pri výchove inžinierov. Je vhodné odštartovat' výučbu s využitím počítačov už aj $\mathrm{v}$ základnom kurze matematiky? Je potrebné, aby študent vedel vypočítat' daný problém aj bez použitia počítača?

Vývoj výpočtovej techniky je vel'mi rýchly, preto je dôležité si uvedomit', čo je nutné minimum, ktoré by mal inžinier zvládnut' aj bez počítača, a na ktoré riešenia môže počítač využívat'. Mali by sme vychovávat' inžinierov, ktorí budú vediet' použit' počítač a dostupné programové vybavenie na odbúranie neefektívnej mechanickej práce (t.j. budú vediet' o jeho existencii a spôsobe použitia). Chceme teda vychovat' inžiniera, ktorý bude vediet', že počítač ho oslobodí od zapamätávania si množstva postupov pri riešení základných úloh. Ak by sme však zamerali svoju výučbu iba na využívanie počítačov a softvér umožňujúci riešit' konkrétne problémy, hrozí, že budeme vychovávat' tzv. „tlačidlových inžinierov“, ktorí nebudú schopní samostatne riešit' nové problémy aplikovaním rozličných, im už známych postupov, pokial' im to pre nich už známy softvér neumožní.

V [9] autori položili z pohl'adu potreby vzdelávania matematiky na vysokých školách niekol'ko vel'mi dôležitých otázok: „Musia všetku matematiku učit' iba matematici? Vieme čo potrebujú odborné predmety z matematiky? Aké je miesto počítačovej podpory výučby matematiky? ". Dnes už na niektoré z nich môžeme na základe našich skúseností odpovedat'.

Z našich skúseností vyplýva, že vhodným postupom je najprv študentovi ukázat' základný dostupný matematický aparát a následne mu ukázat' aj spôsoby a možnosti IKT, ktoré mu zjednodušia často sa opakujúce nevyhnutné postupy k získaniu korektného výsledku. Vd’aka klasickej teoretickej príprave má študent možnost' získat' „matematickú intuíciu“, vd’aka ktorej bude schopný posúdit' použitel'nost' vybranej metódy a rozlíšit' alebo aspoň odhadnút' správnost', resp. nesprávnost' získaného výsledku.

Počas výučby neustále zdôrazňujeme, že študent pri využití softvéru (aj ked' správne zvoleného) nemôže iba slepo verit' získaným výsledkom, pretože pri riešení úloh sa totiž môžu objavit' chyby vyplývajúce z rôznych dôvodov nesprávne použitá metóda, nesprávne nadefinované vstupné parametre a pod. Snažíme sa tiež o to, aby absolvent našej fakulty nebol schopný riešit' problémy iba vtedy, ak ide elektrický prúd a fungujú všetky dostupné IKT, ale aj vtedy, ak tieto vymoženosti dnešnej doby nemá k dispozícii. Minimálne by mal aspoň tušit', aké má možnosti a smery, ktorými by sa pri riešení problémov mohol poberat'. 
Tabul'kové kalkulátory sú v praxi často využívané na spracovávanie rozličných údajov súvisiacich s financiami - na vytváranie splátkových kalendárov pôžičiek, pracovných výkazov, sledovanie výkonnosti zamestnancov, či na analýzu cenných papierov. Spracované údaje následne slúžia napríklad na prezentáciu obchodných výsledkov firmy alebo tiež na usmernenie používatel'a, či investovat' alebo nie do analyzovaného cenného papiera. Tabul'kové kalkulátory totiž poskytujú pomerne jednoducho zvládnutel'né nástroje a ich kombinácia umožňuje aj menej zdatným používatel'om riešit' komplikovanejšie úlohy, pričom často do určitej miery využívanie tabul'kového kalkulátora dokáže nahradit' využívanie drahých informačných systémov a ich databáz.

Tabul'kové kalkulátory možno využit' nielen na jednoduché finančné výpočty, ale taktiež aj na modelovanie komplexnejších finančných štruktúr ako portfólio, hodnotenie reálnych možností investovania a rizík. Na tieto úlohy možno využívat' preddefinované funkcie, ktoré sú dostupné hned' po inštalácii danej aplikácie alebo prostredníctvom rozličných prídavných „modulov“. V prípade nedostatočnej základnej ponuky funkcií je tu v prípade potreby vždy možnost' doprogramovat' si vlastnú funkciu v prostredí Visual Basic.

\section{Požiadavky na absolventov ekonomických fakúlt a potreby praxe}

$\mathrm{Na}$ absolventov rozličných odborov sú prirodzene kladené rôzne požiadavky. Každý zamestnávatel' si stanoví vlastné požiadavky, ktoré musí spĺn̆at' uchádzač o prácu, ak chce uspiet'.

V súčasnosti sa každý absolvent musí vediet' popasovat' so základnými výzvami spoločnosti, najmä s informačnou explóziou, vedeckotechnickým rozvojom a globalizáciou sveta. Vzdelávanie budúcich inžinierov by preto nemalo byt' zamerané iba na teoretické získavanie potrebných vedomostí ale aj na posilnenie schopnosti adaptovat' sa, tvorivo mysliet' a schopnost' sebavzdelávat' sa počas celého života. Je potrebné ich pripravit' na samostatné riešenie vel'mi konkrétnych problémov s využitím svojich vedomostí a dostupných informácií.

V roku 2008 zadala Podnikatel'ská aliancia Slovenska žiadost' na vypracovanie aktivity „Prepojenie vzdelávania spotrebami trhu práce“. Tento dokument vypracovala Uni2010, organizácia rozvíjajúca talent, víziu a podnikavost' mladých l'udí. V prvej kapitole uvádza všeobecné požiadavky zamestnávatel'ov na absolventov [6]:

- Práca S PC a plynulé ovládanie aspoň jedného cudzieho jazyka.

- Vnútorná motivácia pre prácu, ktorá slúži ako hnacia sila pre nasadenie, vôl'u učit' sa, rást' a zodpovedne pristupovat' k zvereným úlohám.

- Komunikatívnost', kreativita, adaptabilita a schopnost' riešit' problémy, ktoré zastupujú najdôležitejšie praktické schopnosti.

$Z$ uvedenej štúdie a analýzy pracovných ponúk na portáli profesia.sk vyplýva, že absolvent štúdia s ekonomickým zameraním (t.j. financie, bankovníctvo, poist'ovníctvo, manažment a pod.) okrem vyššie spomenutých požiadaviek musí splńat' aj d'alšie:

- vodcovské a organizačné schopnosti,

- silný tímový duch, flexibilita, schopnost' analyzovat',

- práca s kancelárskym balíkom MS Office,

- vodičský preukaz skupiny B.

Z vyššie uvedených skutočností vyplýva, že absolvent Ekonomickej fakulty dnes už nemusí byt' zdatný iba voblasti ekonómie, ale je potrebné, aby tieto vedomosti vedel aplikovat' na problémy praxe aktívnym využívaním dostupných IKT.

\section{Využívanie IKT vo vyučovacom procese v rámci bakalárskeho stupňa štúdia na Ekonomickej fakulte Technickej univerzity v Košiciach}

Dnes už neexistuje snád' ani jediná oblast' hospodárstva, kde by IKT nemali svoje miesto. Využívanie IKT ulahčilo aj mnohé činnosti v oblasti ekonómie. Medzi najvýraznejšie oblasti môžeme zaradit': investovanie, e-bankovníctvo, burzovníctvo, riadenie podnikov prostredníctvom informačných systémov [8]. Okrem toho, vzhl'adom na potreby trhu práce, je dôležité, aby si aj naši študenti uvedomovali potrebu znalosti práce $\mathrm{s}$ IKT a orientácie v tejto oblasti.

$\mathrm{V}$ rámci vzdelávania na našej fakulte sa snažíme priebežne inovovat' vzdelávací proces tak, aby kopíroval potreby trhu práce ale zároveň aby reagoval aj na zmeny dejúce sa v spoločnosti (t.j. prechod od informačnej spoločnosti k znalostnej spoločnosti). V tomto kontexte je preto potrebné našich študentov vzdelávat' nielen po odbornej stránke $\mathrm{v}$ oblasti ekonómie, ale aj v oblasti spracovania a využívania informácií ako takých a nástrojov informačných technológií, ktoré im tieto činnosti môžu zjednodušit'. 
Samozrejme, predstava, v akom rozsahu sa IKT vo vzdelávacom procese využívajú, je odlišná na oboch stranách - na strane pedagógov aj na strane vyučujúcich. Naši vyučujúci v poslednom období a najmä aj vd’aka poskytovaniu dištančného vzdelávania [5], objavili široké možnosti IKT (napr. elektronické prezentácie, elektronické zverejňovanie študijných materiálov, modelové príklady, diskusné fóra, elektronické testovanie znalostí študentov a pod.), ktoré aktívne využívajú aj vo vzdelávaní študentov dennej formy štúdia na fakulte.

Iný pohl'ad na vec však majú študenti, ktorí sú častokrát skúsenejší vo využívaní nástrojov IKT a ktorí pravdepodobne vidia ešte viac možností, ako by im tieto technológie mohli v ich štúdiu pomôct'. Aby sme zistili, aký je reálny stav využívania IKT vo vzdelávaní v prostredí našej fakulty, uskutočnili sme v roku 2009 medzi študentmi bakalárskeho stupňa štúdia dotazníkový prieskum.

Na základe realizácie spomínaného prieskumu sa z pohl'adu študentov na fakulte využívajú IKT najmä $\mathrm{v}$ predmetoch zameraných priamo na informatiku prípadne informačné technológie (Informatika I, Informatika II, Kancelárske informačné systémy, Prezentačný softvér a pod.). Navyše z nášho pohl'adu negatívnym výsledkom je aj fakt, že vyučujúci najčastejšie využívajú IKT iba ako nástroj podpory počas prednášok (t.j. prezentácie $\mathrm{v}$ úlohe inovovanej verzie klasicky známych ,priesvitiek“ a meotaru), pričom takmer úplne absentuje využívanie prínosov LMS systémov (Learning Management System Systém na podporu výučby) na zverejňovanie študijných materiálov a na komunikáciu (či už synchrónnu alebo asynchrónnu), vypracovávanie blogov, wiki zadaní a pod.

Z 22 povinných predmetov na bakalárskom stupni štúdia sa IKT a ich možnosti plne využívajú iba v prípade 9 predmetov (využívanie prezentácií, web stránok, LMS systémov a špecializovaných aplikácií na prednáškach aj na cvičeniach) a v prípade 8 predmetov sa IKT využívajú iba na prednáškach. Softvér, vd’aka ktorému študenti môžu aplikovat' svoje teoretické vedomosti na riešenie reálnych alebo fiktívnych problémov, sa využíva iba na štyroch povinných predmetoch (Informatika I, Informatika II, Pravdepodobnost' a štatistika, Štatistické metódy vo finančníctve). V roku 2009 sa 75,56\% študentov z 216 respondentov prieskumu vyjadrilo, že zavedenie IKT do výučby by považovali za prínos najmä vd'aka tomu, že im pomáhajú lepšie pochopit' danú tému alebo konkrétny preberaný problém. Najviac študentov by ocenilo využitie IKT najmä počas štúdia predmetov s matematickým zameraním, kde navrhovali využívanie:

- aplikácií umožňujúcich vykreslovanie grafov (napr. tzv. „,vykresl'ovače“ dostupné prostredníctvom internetu na http://rechneronline.de/function-graphs/, http://graph-plotter.cours-de-math.eu/, http://www.quickmath.com/webMathematic a3/BrowseExamples/Plot.html),

- aplikácie balíka MS Office - MS Excel, ktorý by im ul'ahčil niektoré komplikovanejšie a opakujúce sa výpočty a následne umožnil aj kontrolu nimi získaných výsledkov.

Zaujímavým výsledkom prieskumu je aj návrh študentov, že nie je potrebné/nutné, aby využívanie týchto aplikácií bolo realizované priamo v rámci prezenčnej výučby, ale postačilo by, keby im vyučujúci prostredníctvom využívaného LMS ( $v$ našom prípade LMS Moodle) zverejnili potrebné informácie pre dostupnost' a používanie odporúčaných aplikácií, prípadne „screenshoty“ výsledných zobrazení v daných aplikáciách, aby si v domácom prostredí vedeli získané výsledky overit'.

\section{Príklad posilnenia medzipredmetových vzt'ahov s využitím IKT}

Vzhl'adom na výsledky spomínaného dotazníka a požiadaviek praxe sme sa rozhodli postupne renovovat' ponúkané predmety a zároveň ukázat' ostatným pedagogickým pracovníkom spôsob, akým je možné prostredníctvom využívania IKT zatraktívnit' jednotlivé predmety a zároveň aj posilnit' medzipredmetové vzt'ahy tým, že študenti budú pri riešení nastolených problémov naozaj využívat' aj vedomosti získané $\mathrm{v}$ rámci štúdia iných predmetov.

Už študentom prvého ročníka bakalárskeho štúdia ponúkame v letnom semestri povinne volitel'ný predmet Kancelárske informačné systémy (KIS). Z pohladu informačných technológií tento predmet svojím obsahom nadväzuje na predmety Informatika I a Informatika II, v rámci ktorých sa študenti oboznámia so základmi práce $\mathrm{s}$ aplikáciami kancelárskeho balíka MS Office. Z pohl'adu ekonómie predmet nadväzuje na riešenie problémov z oblasti finančnej matematiky, ktorej sa venovali na predmetoch Mikroekonómia a Matematika I. Konkrétne ide o úlohy týkajúce 
sa úrokovania, rentového počtu, umorovania pôžičiek a analýzy finančných tokov.

Počas výučby predmetu Matematika I zatial' prevláda tradičný spôsob vzdelávania kombinácia tzv. informatívno-receptívneho vyučovania s riešením úloh sprevádzaným vzájomnou diskusiou učitel'a a študenta bez využitia IKT. Preto sa v jednej časti predmetu KIS snažíme skombinovat' teoretické vedomosti študentov získaných pri štúdiu odborných predmetov sich praktickými zručnost’ami a prácou s programom MS Excel. Túto aplikáciu sme zvolili preto, lebo je súčast'ou rozšíreného kancelárskeho balíka MS Office a ktorá zároveň okrem základných matematických a štatistických funkcií ponúka aj pestrú paletu finančných funkcií. Na základe týchto skutočností ju preto považujeme za nástroj vhodný pre lepšie pochopenie problematiky finančnej matematiky.

Podl'a [10] má vyučovací proces okrem iného splńat' aj rozvíjajúcu funkciu, t.j. vzdelávanie má podporovat' rozvoj poznávacích schopností študenta (vrátane kritického myslenia) a rozvoj tvorivých schopností a pružne sa prispôsobovat' rýchle sa meniacim podmienkam života. Preto boli študenti počas semestra postavení pred niekol'ko modelových situácií $\mathrm{z}$ finančnej matematiky rôznej, postupne sa zvyšujúcej obtiažnosti. V každej z nich bolo ich úlohou na základe svojich teoretických vedomostí identifikovat' oblast' finančnej matematiky, ktorej sa situácia týkala, vybrat' z množiny dostupných finančných funkcií programu MS Excel vhodnú funkciu na potrebný výpočet a následne zautomatizovat' jej riešenie.

$\mathrm{Na}$ začiatok, $\mathrm{v}$ snahe pozitívne motivovat' študentov, sme samozrejme zaradili úlohy na porozumenie, t.j. na riešenie ktorých postačí použitie jedinej z preddefinovaných funkcií MS Excel (ako napríklad určenie budúcej hodnoty investície pri pravidelných a konštantných platbách a konštantnej úrokovej miere, či určenie vnútornej miery výnosnosti finančného toku). Potom sme zaradili úlohy, pri riešení ktorých už študenti museli bud' nadefinovat':

- vlastné vzorce (určenie budúcej hodnoty počiatočnej investície za predpokladu, že ešte pred uplynutím stanovenej doby investície vyberieme $\mathrm{z}$ účtu polovicu počiatočnej sumy)

- alebo skombinovat' niekol'ko z funkcii MS Excel (určenie budúcej hodnoty investície pri pravidelných a konštantných platbách a konštantnej úrokovej miere za predpokladu, že interval platieb a úročenia je rôzny - napríklad vklady na účet sa realizujú štvrt'ročne a úročenie na danom účte je mesačné).

Zaujímavost'ou bolo, že pri posledne menovaných úlohách študenti sami uznali, že sú situácie, ked' ovládanie len samotného softvéru určeného na riešenie problému, ale bez dostatočných teoretických vedomostí, na vyriešenie daného problému nepostačuje.

V závere semestra študenti dostali zadanie rozdelené na dve samostatné úlohy $\mathrm{z}$ oblasti finančnej matematiky, pričom počas riešenia museli študenti sami určit', o akú oblast' finančnej matematiky sa jedná.

Jedna úloha sa týkala úrokovania a druhá vytvorenia umorovacieho plánu pôžičky, pričom nezáležalo na tom, či pri riešení využijú funkcie MS Excel, vytvoria si vlastné vzt'ahy alebo použijú kombináciu oboch prístupov. Riešenie týchto úloh sme následne vyhodnocovali.

Riešenia sa zúčastnilo 32 študentov prvého ročníka kombinovanej metódy externej formy štúdia, ktorú na fakulte realizujeme už od roku 2003 [5]. Umorovací plán dokázalo úplne správne aj s overením správnosti postupu zrealizovat' 18 študentov (56,25\%), 10-tim $(31,25 \%)$ sa počiatočné riešenie uberalo správnym smerom, ale neboli si istí, či je to $\mathrm{v}$ poriadku a tak problém nedoriešili a iba štyria $(12,5 \%)$ z nich postupovali bud' úplne nesprávne alebo sa ani nepokúsili daný problém vyriešit'.

Zložitejšia situácia nastala, ked' si študenti mali poradit' s úrokovaním. Ked'že v MS Excel nie je funkcia na výpočet budúcej hodnoty počiatočnej investície $\mathrm{v}$ prípade jednoduchého úrokovania, študenti boli postavení pred úlohu tento problém identifikovat' a následne na základe svojich teoretických vedomostí daný vzt'ah pre výpočet sami vytvorit'.

S úlohou si korektne poradilo 10 študentov $(31,25 \%), 15 \quad(46,88 \%)$ si s úlohou poradilo čiastočne, t.j. zistili síce, že neexistuje funkcia, ale vhodný vzt'ah si už nedokázali vytvorit' alebo ho následne modifikovat' aj pre podmienku zdanenia úrokov. A prekvapujúco 7 študentov $(21,87 \%)$ si súlohou nedokázalo poradit', napriek tomu, že dané úlohy bežne riešili počas štúdia predmetu Matematika I.

\section{Záver}

V [2] sa uvádza, že „Strategická správa o obnovenej lisabonskej stratégii konštatuje iba obmedzený pokrok Slovenska voblastiach modernizácie školstva a vedy, riešenia dlhodobej 
nezamestnanosti azlepšenia podnikatel'ského prostredia".

$\mathrm{Na}$ základe princípov trvalo udržatel'ného rozvoja [3], ciel'mi lisabonskej stratégie [4], ale aj programového vyhlásenia vlády Slovenskej republiky [7] došlo k vytvoreniu programu s názvom Program Slovensko 21 [2]. Nosným pilierom programu sú štyri hlavné oblasti verejnej politiky, ktoré vyplývajú zo Strategickej správy o obnovení lisabonskej stratégie. Jednou z týchto oblastí je vzdelávanie, v ktorej má vláda za ciel' rozpracovat' jednotlivé opatrenia okrem iného aj v oblasti vysokého školstva, aby došlo $\mathrm{k}$ jeho zlepšeniu a napredovaniu.

Ako vyplýva $\mathrm{z}[1]$, z pohl'adu praxe sú najžiadanejšími absolventi informaticky orientovaných fakúlt, pričom vel'mi dobré postavenie na trhu práce majú aj absolventi stavebných a ekonomicky orientovaných fakúlt. V súčasnosti sa o našich absolventov (t.j. študentov ekonomických fakúlt) zaujíma približne 39,6 \% potenciálnych zamestnávatel'ov.

Z pohl'adu d'alšieho napredovania našej fakulty a jej integrácie do európskeho vzdelávacieho priestoru, by malo byt' naším ciel'om pripravit' našich absolventov tak, aby každý z nich mal na trhu práce svoje miesto a zamestnávatelia by ich na pohovoroch automaticky radili medzi kvalitných pracovníkov, ktorí majú prehl'ad v oblasti svojho štúdia, dokážu tvorivo mysliet' a riešit' úlohy za aktívneho využívania všetkých dostupných informačných kanálov a technologických nástrojov s návykmi pravidelného samovzdelávania. Aby sme však tento ciel' dosiahli, je potrebné v poskytovanom vzdelávaní vykonat' určité zmeny. V súčasnosti totiž už nepostačujú len ,namemorované“ vedomosti.

V rámci príspevku sme preto ukázali jeden zo spôsobov, ako môžeme aj prostredníctvom volitel'ných predmetov využívajúcich IKT zatraktívnit’ štúdium zo strany študentov tak málo zaujímavej matematiky.

\section{Literatúra}

[1] JAKUŠ, D., PÁLENÍKOVÁ, M.: Záujem zamestnávatel'ov o absolventov VŠ (online). [cit. 2010-07-09], URL: <http://fm.tnuni.sk>.

[2] Modernizačný program Slovensko 21, (online) [cit. 2010-03-03]. URL: $<$ http://www.minedu.sk $>$.

[3] Národná stratégia trvalo udržatel'ného rozvoja (online). [cit. 2010-03-03]. URL: $<$ http://www.tur.vlada.gov.sk $>$.
[4] Oblasti a ciele Lisabonskej stratégie pre Slovensko (online). [cit. 2010-07-29], URL: $<$ http://www.euroinfo.gov.sk $>$

[5] PAL'OVÁ, D., RÉVÉSZOVÁ, L.: Experience with the distance learning bachelor study in the field of finance, banking and investment, International journal of emerging technologies in learning, Ročník 5, špeciálne číslo 2, s. 27-31, ISSN: 1863-0383 (online).

[6] Prepojenie vzdelávania s potrebami trhu práce. (online). [cit. 2010-02-10]. URL: $<$ http://www.alianciapas.sk $>$.

[7] Programové vyhlásenie vlády Slovenskej republiky 2006 (online). [cit. 2010-03-03]. URL: $<$ http://www.zbierka.sk>.

[8] RÉVÉSZOVÁ, L., MIHÓK, P.: Informačné systémy pre ekonómov, 1.vyd., Ekonomická fakulta TUKE, Košice, 133 s., 2006, ISBN 808073-497-6

[9] ŠOLTÉS, V., PIRČ, V.: Niektoré problémy matematickej prípravy inžinierov, Hodnotenie učebných plánov, Zborník prác zo seminára v rámci programu TEMPUS S-JEP 11530-96, Herl'any, 20. - 21. novembra 1997, Ekonomická fakulta Technickej univerzity v Košiciach, CPRESS Košice, 1997, s. 5 - 8, ISBN 80-7099321-9.

[10] TUREK, I.: Úvod do didaktiky vysokej školy, Katedra inžinierskej pedagogiky Technickej univerzity v Košiciach, 318 s., 2005, ISBN 80-7099-882-2.

Ing. Dana Pal'ová, PhD.

Katedra aplikovanej matematiky

a hospodárskej informatiky

Ekonomická fakulta, Technická univerzita

v Košiciach

Nemcovej 32

040 01, Košice, SR

Tel: +421 0556023268

E-mail: dana.palova@tuke.sk

Www pracoviště: www3.ekf.tuke.sk/kamahi

RNDr. Dáša Hudáková, PhD.

Katedra aplikovanej matematiky

a hospodárskej informatiky

Ekonomická fakulta, Technická univerzita

v Košiciach

Nemcovej 32

040 01, Košice, SR

Tel: +421 0556023268

E-mail: dasa.hudakova@tuke.sk

Www pracoviště: www3.ekf.tuke.sk/kamahi 